statecznie naświetlona przez historyków ukraińskich, prace wcześniejsze traktowały ten temat dosyć powierzchownie, dlatego badania autora niniejszego artykułu wydają się potrzebne, a wykorzystane i przedstawione źródła w zupełnie inny sposób naświetlają mało zbadane karty wydarzeń, podważając przy tym rozpowszechnioną współcześnie w ukraińskiej historycznej nauce koncepcję „,ukraińsko-rosyjskiej wojny" ${ }^{20}$. Autor poddaje krytyce wcześniejsze nieliczne badania tego tematu w związku z wykorzystaniem przez badaczy jedynie źródeł narracyjnych. W swoim artykule I. B. Babulin wykorzystuje źródła archiwalne przechowywane w Rosyjskim Państwowym Archiwum Akt Dawnych.

Recenzowane wydanie zamyka artykuł D. Z. Feldmana o Żydach ochrzczonych służących w pułkach słowianoserbskich w Rosji w wieku XVIII ${ }^{21}$. Autor ustalił, że odsetek ochrzczonych Żydów na służbie w wojsku carskim w wieku XVIII sięgał zaledwie $1 \%$.

Książka stanowi novum na rynku wydawniczym z racji tego, że upowszechnia informacje dostępne dotychczas wąskiej grupie badaczy. Odnosi się to zarówno do specjalistów w zakresie wojskowości, jak i znawców dziedzin pokrewnych. Ten cel autorów z pewnością został osiągnięty. Wielce pożądanym sukcesem w przyszłości byłoby z kolei wywołanie zainteresowania książką również wśród historyków i miłośników wojskowości pochodzących z Europy Zachodniej.

Viktoria Dzianisava (Toruń, Mińsk)

\title{
Jacek Krupa, Żydzi w Rzeczypospolitej w czasach Augusta II (1697-1733), Kraków 2009, ss. 260
}

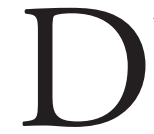
wa lata temu na polskim rynku wydawniczym w ramach Studia Judaica Cracoviensia Series Dissertationum III ukazała się monografia pióra Jacka Krupy zatytułowana Żydzi w Rzeczypospolitej w czasach Augusta II (1697-1733). Autor recenzowanej monografii - dr Jacek Krupa jest obecnie wykładowcą na Uniwersytecie Jagiellońskim w Krakowie, gdzie zatrudniony jest na stanowi-

20 Ibidem, s. 254.

21 Д. 3. Фельдман, Крещенные евреи в составе слдовяно-сербских полков России в середине XVIII в., [w:] Единорогъ, s. 290-293. 
sku adiunkta w Zakładzie Historii Żydów Katedry Judaistyki. Jego zainteresowania naukowe obejmują przede wszystkim dzieje Żydów na ziemiach polskich w XIX wieku, problematykę żydowską i relacje pomiędzy władzami dawnej Rzeczypospolitej a społecznością żydowską w państwie szlacheckim, historię Polski i historię powszechną w czasach nowożytnych i w wieku XIX oraz dzieje polskiego parlamentaryzmu. W swoim dorobku naukowym Jacek Krupa koncentruje się zwłaszcza na kwestii żydowskiej w Rzeczypospolitej w czasach saskich ${ }^{1}$.

Recenzowana książka, oddana do rąk czytelników w roku 2009, w moim odczuciu zapisała się jako interesujące studium dotyczące problematyki żydowskiej w czasach saskich, gdyż była to pierwsza tego typu pozycja, z jaką czytelnik zainteresowany kwestią żydowską w omawianym okresie mógł się zetknąć. Słusznie zauważył sam autor, że literatura związana z tematyka żydowską poruszaną na sejmikach i sejmach dawnej Rzeczypospolitej nie jest zbyt obfita ${ }^{2}$, a kwestie dotyczące postawy króla Augusta II wobec polskich Żydów czy relacje ludności żydowskiej z naczelnymi organami państwa i szlacheckimi właścicielami miast i dóbr w XVIII wieku - znaleźć możemy jedynie jeszcze w pracach Jakuba Goldeberga, Janusza Fałkowskiego, Gershona Davida Hunderta, Moshe J. Rosmana i A. Kaźmierczyka ${ }^{3}$.

${ }^{1}$ Poniżej znajduje się wykaz najważniejszych publikacji dr. Jacka Krupy: Parlamentary acts concerning the Jews In the Polish Commonwelth during the reign of King Augustus II the Strong (1697-1733), [in:] Scripta Judaica Cracoviensia, vol. 1, Kraków 2002, pp. 53-64; Source Materials to the History of the Jews in the Lublin City Registers from the Reign of Augustus II Sas 1697-1733, H. Gmiterek (ed.), prefaced by A. Teller, Lublin 2001, [in:] Scripta Judaica Cracoviensia, vol. 1, Kraków 2002, pp. 135-137; Konfederacje szlacheckie wobec Żydów za Augusta II, [w:] Rzeczpospolita wielu wyznań, red. A. Kaźmierczyk, A. K. Link-Lenczowski, M. Markiewicz, K. Matwijowski, Kraków 2004, s. 135-144; Postrzeganie Żydów w Rzeczypospolitej w czasach saskich, [w:] Staropolski ogląd swiata, red. B. Rok i F. Wolański, Wrocław 2004, s. 225-231; Żydzi w Rzeczypospolitej w czasach saskich - ludzie pogranicza, [w:] Między Zachodem a Wschodem. Etniczne, kulturowe i religijne pogranicza Rzeczypospolitej $w$ XVI-XVIII wieku, red. K. Mikulski i A. Zielińska-Nowicka, Toruń 2005, s. 216-222; Behrendt Lehmann-żydowski klient czy patron w Rzeczypospolitej Augusta II, [w:] Patron i dwór. Magnateria Rzeczypospolitej w XVIXVIII wieku, red. E. Dubas-Urwanowicz i J. Urbanowicz, Warszawa 2006, s. 155-163; Poczucie zagrożenia w życiu codziennym w czasach Augusta II w świetle przekazów źródtowych z początku XVIII wieku, [w:] Między barokiem a oświeceniem. Radości i troski dnia codziennego, red. S. Achremczyk, Olsztyn 2006, s. 258-266; Żydzi sefardyjscy w Polsce - inny świat Rzeczypospolitej, [w:] Staropolski oglą świata - problem inności, red. F. Wolański, Toruń 2007, s. 66-74; Polityka królewska wobec Żydów w czasach Augusta II Mocnego (1697-1733), [w:] Spory o państwo $w$ dobie nowożytnej. Między racją stanu a partykularyzmem, red. Z. Anusik, Łódź 2007, s. $161-174$.

${ }^{2}$ J. Krupa, Żydzi w Rzeczypospolitej w czasach Augusta II, s. 12.

3 Ibidem, przypis 22 i 24, s. 12-13. 
Książka Żydzi w Rzeczypospolitej w czasach Augusta II (1697-1733) jest pracą analityczną, a tezy w niej zawarte autor oparł na kwerendzie źródłowej w wielu archiwach, m.in. w Archiwum Akt Nowych w Warszawie, w Archiwum Państwowym w Krakowie, Lublinie, Rzeszowie oraz w Bibliotekach: Czartoryskich i Jagiellońskiej w Krakowie, PAN w Kórniku i Krakowie. Dr Jacek Krupa czerpał informacje z analizy diariuszy sejmowych i materiałów sejmikowych (m.in. mazowieckich, sandomierskich, lubelskich), zawierających lauda i instrukcje poselskie (m.in. krakowskie, średzkie i pruskie). Autor ponadto uwzględnił materiał źródłowy dotyczący diariuszy konfederacji tarnogrodzkiej, akta kancelarii Jana Szembeka, listy (Augusta II, Jana Szembeka, Jana Jerzego Przebendowskiego i inne ) oraz pamiętniki z początku XVIII wieku, literaturę polemiczną, gazety pisane, publicystykę czasów saskich i Volumina Legum.

Tytuł książki jest jak najbardziej adekwatny do podjętej w niej tematyki. Praca ma charakter problemowy. Prezentuje zagadnienia dotyczące sytuacji Żydów w Rzeczypospolitej w czasach Augusta II (1697-1733), ilustruje postawy i poczynania względem ludności żydowskiej organów władzy, króla, ministrów, sejmu, sejmików i konfederacji, a także magnatów, szlachty, Kościoła i poszczególnych miast.

Konstrukcja pracy nie budzi absolutnie żadnych zastrzeżeń. We wstępnie zamieszczona została przedmowa pióra autora, który przedstawia w niej stan badań nad podjętą tematyką oraz podkreśla, iż Rzeczypospolita nieprzypadkowo była określana w ówczesnym czasie jako paradisus judeorum ${ }^{4}$. Powszechnie wiadomo, że przez wiele stuleci państwo polsko-litewskie było dogodnym i bezpiecznym miejscem, do którego chętnie przybywały całe rzesze ludności żydowskiej, prześladowanej w innych krajach. W państwie szlacheckim bowiem Żydzi uzyskali opiekę, rozległa autonomię, przyzwolenie na swobodne wyznawanie własnej religii, budowę własnego samorządu terytorialnego, bożnic i szkół, zakładanie cmentarzy czy rozwijanie własnej kultury i tradycjis.

Książka podzielona została na pięć rozdziałów, w których autor skrupulatnie przedstawia postawę: Augusta II i jego ministrów, sejmu, sejmików partykularnych oraz konfederacji wobec ludności żydowskiej w Rzeczypospolitej. W poszczególnych częściach czytelnik może znaleźć szczegółowe informacje dotyczące ustaw sejmowych oraz kwestii problemów żydowskich w wielu aspektach, w szczególności na płaszczyznach gospodarczych, finansowych, społecznych, kulturalnych i religijnych. Z jednej strony Jacek Krupa prezentuje istniejący wówczas negatywny obraz Żyda, by w podsumowaniu swych rozważań konsekwentnie podkreślić jego silną pozycję ekonomiczną oraz przychylność wobec niego samego króla oraz większo-

\footnotetext{
${ }^{4}$ Ibidem, s. 7.

${ }^{5}$ Ibidem.
} 
ści społeczeństwa Rzeczypospolitej. W czasie panowania Augusta II Żydzi bowiem czynnie uczestniczyli w życiu gospodarczym państwa jako kupcy, rzemieślnicy, a nawet bankierzy czy urzędnicy w administracji celnej i skarbowej. Sam król także oraz jego ministrowie brali niejednokrotnie Żydów w opiekę i w większości przypadków byli im przychylni ${ }^{6}$. Analiza materiałów sejmowych

nasuwa wniosek, że szlachta, ostro atakując Żydów w czasie obrad [...] zdawała sobie jednocześnie sprawę z pozytywnych cech społeczności żydowskiej. Chociaż rozlegały się głosy, żądające usunięcia Żydów z poszczególnych dzielnic (Mazowsze) lub nawet z całego kraju, to jednak szlachta potrafiła również docenić ich rolę dla rozwoju miast. [...] Wielokrotnie też mieszkańcy mniejszych miast potrafili przyjaźnie układać współpracę z ludnością żydowską, pomimo ostrej konkurencji pomiędzy kupcami chrześcijańskimi a żydowskimi [...] $]^{7}$.

$\mathrm{Na}$ ocenę pracy poważny wpływ ma charakter publikacji. Niewątpliwie zamysłem autora było napisanie pracy ściśle analitycznej. W moim odczuciu autor wykazał się dobrą znajomością poruszanej problematyki na płaszczyźnie podejmowanych przez Augusta II, ministrów, sejm, sejmiki i konfederacje decyzji dotyczących Żydów. W związku z czym recenzowana praca uzupełnia nasz dotychczasowy stan wiedzy na temat postrzegania ludności żydowskiej przez szlachtę zebraną na sejmikach, w szczególności na sejmikach partykularnych czy konfederacjach oraz pozwala uchwycić pewne elementy polityki Augusta II wobec Żydów w Rzeczypospolitej. Zastosowany w niej natomiast niezbędny aparat naukowy ułatwia analizę i ocenę mechanizmów kształtowania się postaw wobec ludności żydowskiej w czasach saskich.

Zamierzeniem autora książki było także ukazanie relacji państwa szlacheckiego wobec żydowskich poddanych w okresie, kiedy na tronie Rzeczypospolitej zasiadała August II z dynastii Wettynów. Cel ten niewątpliwie osiągnął, a stanowisko Rzeczypospolitej wobec Żydów było wypadkową decyzji władz publicznych, poczynań wymiaru sprawiedliwości, postawy Kościoła oraz wielu ważnych powiązań czy nieformalnych relacji pomiędzy różnymi elementami struktury społecznej dawnej Rzeczypospolitej ${ }^{8}$.

$\mathrm{Na}$ ich sytuację i pozycję miał również wpływ niepokój społeczny związany z działaniami militarnymi w czasie wojny północnej’. Idąc ponadto za stwierdzeniem Władysława Smoleńskiego, należy zauważyć, że „Żydzi byli takimi jakimi ich

${ }^{6}$ Ibidem, s. 214

7 Ibidem, s. 212

8 Ibidem, s. 9.

9 Ibidem. 
zrobily prawa szlacheckie"10. Niestety, recenzowana monografia w wielu aspektach nie wyczerpuje problematyki. Szczególne miejsce w pracy zajmują przede wszystkim aspekty dotyczące poczynań organów władzy Rzeczypospolitej względem Żydów, a zagadnienia dotyczące sytuacji ludności żydowskiej czy postaw wobec niej Kościoła, szlacheckich właścicieli i poszczególnych miast potraktowane zostały przez Jacka Krupę raczej marginalnie. Sam autor zaznacza jednakże, że pomimo tego, iż „powyższe kwestie znalazły w pracy odzwierciedlenie, są poruszane tylko w takim zakresie, w jakim tworzą niezbędne tło dla opisywanych zjawisk"11.

$\mathrm{Na}$ końcu monografii autor zamieścił odautorską konkluzję. Jest to znakomita klamra spinająca bardzo interesującą całość. Ponadto czytelnik może odnaleźć na końcu pozycji również wykaz skrótów, obszerną bibliografię oraz indeks osobowy i geograficzny.

W moim odczuciu tytułowa problematyka, przedstawiona w ciekawej formie, doczekała się dobrego opracowania, opartego na dobrze dobranej bazie źródłowej. W pięciu rozdziałach autor dostarcza czytelnikom dużą ilość szczegółowych informacji. Lektura książki Jacka Krupy może być wielce pożyteczna dla czytelnika zainteresowanego wskazaną tematyką, gdyż moim zdaniem jest interesująca i napisana w przystępny sposób. Natomiast dzięki obfitej bibliografii staje się cenną wskazówką bibliograficzną w sferze materiałów źródłowych i literatury. W mojej opinii książka Jacka Krupy jest godną uwagi pozycją, którą w całej rozciągłości gorąco polecam osobom, zwłaszcza zainteresowanym problematyką żydowską w czasach saskich.

Sylwia Getka-Pesta (Toruń)

${ }_{10}$ W. Smoleński, Mieszczaństwo warszawskie w końcu XVIII wieku, oprac. i wstęp M. H. Serejski, A. Wierzbicki, Warszawa 1986, s. 25.

${ }^{11}$ J. Krupa, Żydzi w Rzeczypospolitej w czasach Augusta II, s. 15. 
(ㄷ) 이 9 